Економічні науки: збірник наукових праиь Луиького національного технічного університету. - Серія "Регіональна економіка". - Випуск 15 (59). - Редкол.: відп. ред. д.е.н., професор Л.Л. Ковальська - Луцьк : ІВВ Луцького НТУ, 2018. -292 с.

УДК 332.2

Шубалий О.М., д. е. н., професор

Косінський П.М., аспірант

Луцький національний технічний університет

\title{
ЕКОНОМІЧНЕ СТИМУЛЮВАННЯ РОЗВИТКУ КОМПЛЕКСНИХ ВИРОБНИЦТВ ІЗ ВИДОБУТКУ ТА ПЕРЕРОБКИ САПРОПЕЛЮ В РЕГІОНІ
}

У статті визначено можливості використання сапропелю у різних сферах промисловості. Було визначено запаси сапропелю у Волинській області, площу під ними. Визначено можливі позитивні наслідки від видобутку та переробки сапропелю. Обгрунтовано доцільність створення та розвитку промислових підприємств із переробки сапропелю.

Ключові слова: сапропель, донні відклади, промислова переробка, переробні виробництва, економічне стимулювання. 

університету. - Серія "Регіональна економіка". - Випуск 15 (59). - Редкол.: відп. ред. д.е.н., професор Л.Л. Ковальська - Луцьк : ІВВ Луцького НТУ, 2018. -292 с.

Shubalyi O., Kosinskyi P.

\section{THE ECONOMIC IMPROVEMENT OF DEVELOPMENT OF INTEGRATED MANUFACTURING FROM PRODUCTION AND PROCESSING OF SAPROPEL IN THE REGION}

The article states that global trends are aimed at providing economies with resources. Therefore, the search for alternative sources of resources remains relevant.

One of the important natural resources that can find its application in various spheres of industry is sapropel, deposited at the bottom of reservoirs of natural and artificial origin.

At the bottom of the reservoirs located within the territory of the Volyn region, very large deposits of sapropel have been discovered, which create the potential and prospects for the development of processing industries on the basis of this natural resource. The use of sapropel is possible in various fields of industry: agriculture, medicine, chemical industry, construction materials industry, etc.

In the course of the study, reserves of lake deposits in the Volyn region were determined, due to the importance and feasibility of establishing enterprises for extraction and processing of this natural resource. The tools of economic stimulation of development and extraction of sapropel in the region are proposed.

Key words: sapropel, bottom sediments, industrial processing, processing production, economic stimulation.

\section{Шубалый А.М., Косинский П.М. \\ ЭКОНОМИЧЕСКОЕ СТИМУЛИРОВАНИЕ РАЗВИТИЯ КОМПЛЕКСНЫХ ПРОИЗВОДСТВ ПО ДОБЫЧЕ И ПЕРЕРАБОТКЕ САПРОПЕЛЯ В РЕГИОНЕ}

В статье определены возможности использования сапропеля в различных сферах промышленности. Было определено запасы сапропеля в Волынской области, площадь под ними. Определены возможные положительные последствия от добычи и переработки сапропеля. Обоснована целесообразность создания и развития промышленных предприятий по переработке сапропеля.

Ключевые слова: сапропель, донные отложения, промышленная переработка, перерабатывающие производства, экономическое стимулирование.

Постановка проблеми у загальному вигляді і її зв'язок 3 важливими науковими та практичними завданнями. 
Економічні науки: збірник наукових праиь Луиького національного технічного університету. - Серія "Регіональна економіка". - Випуск 15 (59). - Редкол.: відп. ред. д.е.н., професор Л.Л. Ковальська - Луцьк : ІВВ Луцького НТУ, 2018. -292 с.

Сьогодні, світові тенденції спрямовані на забезпечення економіки ресурсами. Тому, актуальним залишається пошук альтернативних джерел ресурсів.

Одним, із важливих природних ресурсів, що може знайти своє застосування в різних сферах промисловості є сапропель, що відкладається на дні водойм природного та штучного походження.

Волинь багата річками та озерами. Густота гідрографічної сітки тут у два рази більша, ніж в середньому по Україні. Її річки належать до басейну Прип'яті і частково - Західного Бугу. У межах області виділяють три великі озерні райони: басейн Західного Бугу, межиріччя Західного Бугу і Прип’яті, басейн Прип'яті.

На дні озер, що знаходяться в межах території досліджуваного регіону зафіксовано дуже велику кількість сапропельних відкладів, що створюють потенціал та перспективи розвитку переробних виробництв на основі даного природного ресурсу.

Аналіз останніх досліджень, у яких започатковано вирішення проблеми. Дослідженнями запасів сапропелів, доцільністю їх видобутку, перспективами раціонального використання та впливом на природні екосистеми займалось багато вітчизняних вчених, зокрема такі, як: Ільїн Л.В., Мольчак Я.О., Шевчук М.Й., Горун А.А., Соловко Д.І. [1-4] та iн.

Цілі статті. Метою даної статті $є$ визначення запасів сапропельних відкладів у водоймах Волинської області та потенціалу створення і розвитку переробних виробництв на його основі; обгрунтування доцільності створення таких виробництв у межах території досліджуваного регіону.

Виклад основного матеріалу дослідження 3 повним обгрунтуванням отриманих наукових результатів. Даючи характеристику водним об'єктам області, неможливо промовчати про наявність такого цінного природного ресурсу, як сапропель.

Сапропель представляє собою донні відклади мінерально- 
Економічні науки: збірник наукових праџь Луцького національного технічного університету. - Серія "Регіональна економіка". - Випуск 15 (59). - Редкол.: відп. ред. д.е.н., професор Л.Л. Ковальська - Луцьк : ІВВ Луцьького НТУ, 2018. -292 с.

органічного походження, які містять понад $15 \%$ маси органічних речовин $[1 ; 2]$.

Донні відклади водойм повільного водообміну - джерело сировини для галузі землеробства, тваринництва, промисловості будівельних матеріалів, медицини та ін [4].

Таким чином, використання сапропелю можливе в різних сферах промисловості, зокрема у: сільському господарстві, медицині, хімічній промисловості, промисловості будівельних матеріалів тощо.

У землеробстві сапропелі можна використовувати для отримання добрив. Завдяки високим сорбційним властивостям сапропелі можуть слугувати природною сировиною для високоефективних комплексних повнокомпонентних добрив, а також складовою частиною різних видів компостів [2].

Використання сапропелів у якості добрив може витіснити 3 ринку інші добрива хімічного (синтетичного) походження, що позитивно відобразиться на загальному здоров 1 сільськогосподарських тварин, може запобігти потраплянню шкідливих хімікатів у грунт, таким чином покращить екологічний стан навколишнього природного середовища.

Сапропель - це цінна мінерально-вітамінна добавка для всіх сільськогосподарських тварин. Під час добавляння в раціон сапропелю у тварин знижується захворюваність, збільшується продуктивність, підвищуються показники надоїв у молочних тварин, зростає жирність молока, покращується обмін речовин у тварин, засвоюваність білкових й інших речовин із концентрованих кормів, у поєднанні з яким його рекомендовано використовувати [5].

Сапропель можна використовувати як сировину для виробництва асортименту будівельних товарів.

У промисловості будівельних матеріалів сухий гранульований органічний сапропель можна використовувати як вигоральну добавку в технології виробництва простих дренажних керамічних труб тощо. Дрібнодисперсну сапропелеву суспензію 3 умістом азоту понад $3 \%$ використовують для виробництва деревоволокнистих плит, 
Економічні науки: збірник наукових праџь Луцького національного технічного університету. - Серія "Регіональна економіка". - Випуск 15 (59). - Редкол.: відп. ред. д.е.н., професор Л.Л. Ковальська - Луцьк : ІВВ Луцьккого НТУ, 2018. -292 с.

теплоізоляційних матеріалів. Сапропелі використовують у ливарному виробництві, у геології - як компоненти розчинів під час буріння свердловин [6].

Сапропелі здавна використовують в медицині як лікувальні грязі й для отримання на їх основі медичних препаратів. Для таких цілей підходять малозольні органічні сапропелі, які містять сірководень, аміно- та карбонові кислоти, макро-, мікроелементи, фізіоактивні гумінові речовини [7].

Найбільші запаси сапропелю знаходяться у Ратнівському, Шацькому, Старовижівському, Любешівському та Турійському районах.

Розвиток видобутку та переробки сапропелю в області потрібно стимулювати за допомогою таких заходів економічного стимулювання:

- фінансова підтримка підприємств із видобутку i переробки донних відкладів зі сторони держави та місцевих територіальних громад - інвестувати кошти в розвиток переробних виробництв 3 державного та місцевого бюджетів, а також за рахунок індивідуальних інвесторів, попередньо створивши для них оптимальний інвестиційний клімат; виділення державою чи, наприклад, екологічними фондами, фінансових коштів цільового характеру на розвиток підприємств із переробки сапропелю, що передбачають екологізацію навколишнього середовища; встановлення пільгового режиму оподаткування підприємств 3 іноземними інвестиціями та ін.;

- прийняття відповідного законодавства, яке б стимулювало видобуток та переробку сапропелю в регіонах його залягання;

- державна підтримка та супровід проектів у сфері енергота ресурсозбереження;

- зараховувати податки переробних підприємств до бюджетів відповідних територіальних громад для підвищення їх зацікавленості у прозорості даного виду діяльності тощо.

Дані про озерні відклади (сапропелі) у Волинській області подано в табл. 1. 
Економічні науки: збірник наукових праџь Луцького національного технічного університету. - Серія "Регіональна економіка". - Випуск 15 (59). - Редкол.: відп. ред. д.е.н., професор Л.Л. Ковальська - Луцьк : ІВВ Луиького НТУ, 2018. -292 с.

Таблиця 1

Озерні відклади (сапропелі) у Волинській області

\begin{tabular}{|l|c|c|c|c|}
\hline \multicolumn{1}{|c|}{ Район } & $\begin{array}{c}\text { Сапропель, } \\
\text { тис. куб. м }\end{array}$ & $\begin{array}{c}\text { Площа під } \\
\text { сапрелем, } \\
\text { га }\end{array}$ & $\begin{array}{c}\text { Середня } \\
\text { глибина } \\
\text { сапропелю, } \\
\text { м }\end{array}$ & $\begin{array}{c}\text { Запаси } \\
60 \% \\
\text { вологості, } \\
\text { тис. т }\end{array}$ \\
\hline Ратнівський & 57149,8 & 4427,6 & 2,8 & 14578 \\
\hline Шацький & 49590,0 & 1302,5 & 4,2 & 9483 \\
\hline Старовижівський & 31463,6 & 829,5 & 3,4 & 8564 \\
\hline Любешівський & 26236,2 & 44050,2 & 2,4 & 8220 \\
\hline Турійський & 10996,2 & 358,8 & 3,1 & 4976 \\
\hline $\begin{array}{l}\text { Камінь- } \\
\text { Каширський }\end{array}$ & 9667,7 & 342,3 & 2,9 & 2610 \\
\hline Ковельський & 8705,0 & 227,6 & 3,6 & 2244 \\
\hline Маневицький & 8078,8 & 219,0 & 3,3 & 1862 \\
\hline Любомльський & 5458,4 & 167,3 & 3,6 & 2786 \\
\hline Локачинський & 2335,0 & 81,9 & 3,4 & 2335 \\
\hline Рожищенський & 1785,2 & 47,5 & 3,7 & 834 \\
\hline $\begin{array}{l}\text { Володимир- } \\
\text { Волинський }\end{array}$ & 1627,0 & 100,3 & 2,1 & 1328 \\
\hline Іваничівський & 1013,0 & 49,1 & 2,0 & 905 \\
\hline Ківерцівський & 403,0 & 11,1 & 3,9 & 119 \\
\hline Горохівський & 96,0 & 1,4 & 6,9 & 38 \\
\hline Луцький & 37,0 & 3,7 & 1,0 & 37 \\
\hline Всього: & 214641,9 & 52219,7 & $1-6,9$ & 60919 \\
\hline
\end{tabular}

Побудовано на основі джерела [1].

Висновки. Таким чином, видобуток та промислова переробка сапропелю на Волині є економічно вигідними для бюджету області. Тому, доцільно проводити видобуток та будувати підприємства 3 переробки сапропелю у зонах, де його запаси є найбільшими. 
Економічні науки: збірник наукових праџь Луцького національного технічного університету. - Серія "Регіональна економіка". - Випуск 15 (59). - Редкол.: відп. ред. д.е.н., професор Л.Л. Ковальська - Луцьк : ІВВ Луиького НТУ, 2018. -292 с.

До того, ж видобуток сапропелю вирішить ряд проблем екологічного характеру: комплексне відновлення озер покращить водний баланс і якість води, умови для рибальства, сприятиме створенню нових рекреаційних територій; вирощування екологічно чистої сільськогосподарської продукції шляхом використання добрив, кормів та добавок на основі сапропелю.

1. Ільїн Л.В. Озера Волині [Текст]: лімно- географічна характеристика / Л.В. Ільїн, Я.О. Мольчак; Волинський держ. ун-т ім. Лесі Українки, Державне управління екологічної безпеки у Волинській області. - Луцьк: Надстир'я, 2000. - 138 с.: іл. - Бібліогр.: с. 130-138. - ISBN 966-517-244-1.

2. Шевчук М.Й. Сапропелі України: запаси, якість та перспективи використання: монографія / М.Й. Шевчук. - Луцьк: Надстир'я, 1996. - 384 с.

3. Горун А.А. Доцільність видобутку сапропелю та вплив його на природні екосистеми / А.А. Горун // Науковий вісник Волинського національного університету імені Лесі Українки. - 2007. - Вип. 11. - Ч. 1. C. $121-129$.

4. Соловко Д.І. Перспективи раціонального використання сапропелевих ресурсів водойм Волинської області / Д.І. Соловко // Науковий вісник Волинського національного університету імені Лесі Українки. - 2012. - Вип. 18 (243). - C. 23-27.

5. Озерні сапропелі України: збірник технологій і рекомендацій щодо використання сапропелів, у т. ч. на забруднених радіонуклідами землях, нормативних актів, довідкових матеріалів / за ред. Е.Г. Дегодюка, М.Й. Шевчука. - Луцьк: Надстир'я, 1996. - 188 с.

6. Лиштван И.И. Использование сапропелей в народном хозяйстве. Минск: [б. и.], 1976. - С. 5-13.

7. Ільїн Л.В. Лімнокомплекси Українського Полісся: у 2-х т. Т. 2: Регіональні особливості та оптимізація / Ільїн Л.В. - Луцьк: Ред.-вид. від. «Вежа» Волин. нац. ун-ту ім. Лесі Українки, 2008. - 400 с. 